\title{
船首船底波浪衝擊に関寸る模型実驗
}

$\begin{array}{lllll}\text { 正員 工学博士 } & \text { 吉 } \text { 識 雅 夫 } \\ \text { 正員工学士 山 } & \text { 本 } & \text { 善 } \\ \text { 正員 工学士 } & \text { 藤 } & \text { 田 } & \text { 讓 }\end{array}$

\author{
Abstract. \\ On the Slamming. Test of a Wooden Model Ship. \\ By Masao Yoshiki, Kogakuhakushi, Member, \\ Yoshiyuki. Yamamoto, Kogakushi, Member, \\ and Yuzuru Fujita, Kogakushi, Member.
}

The authors performed towing test of a wooden model ship under regular waves and measured the pressure distributions at foreward bottom of the model when she was slamming, by using 19 specially designed pressure gauges.

The maximum pressure observed reached about 4 to 5 times of static pressure under regular waves and position of maximum pressure located about $0.1 \mathrm{~L}$ from F.P., and dynamical pressure became practically zero at about $0.25 \mathrm{~L}$ from F. P..

According to the experimental results; maximum pressure seemed to be related to the relative normal velocity of ship to wave rather than pitching or heaving velocity. And this result is expected from rough theoretical consideration written in Appendix and this maximum pressure can also be estimated from the pressure measured by falling test of flat or wedge shaped body on the surface of water.

Slamming appeared when the ratio of length of wave to that of ship became about 1.1 to 1.2 in this test.

\section{§1. 序带}

船首船底のスラミングによる損鹪は近年に於ても全く跡を絶つたとは云い難く, 種々の研究が発表されてい る。この種の損傷の対策を考える為には, 第一に船首船底に生ずる圧力の大きさ及びその分布を知るごとが大切 であるが，実験計測の困蜼の為に，未だ信頼すべき実験結果が発表されていない。

著者等は長さ $2.5 \mathrm{~m}$ の日聖丸 (日産汽船) 木製摸型を使用し，その船首船底に F. P.から $0.3 \mathrm{~L}$ の間に 19 籄の水压計を配置して，抵抗水槽で波浪中の曳行実験を行い，スラミング時の水圧分布を测定した。初めて の試みであるから改善を要すべき点もあると思われるが，一応の絬果を得たので．ここに発表して大方の御批判 を仰ぎ，この種実験の発展を図り。併せて船首船底の損鹪解明に奇与したいと考える次第である。

\section{§2. 模型実験の概略}

a) 模型船沉ついて

本実験に使用した模型船は日聖丸の $1 / 51.2$ の模型で，その主要寸法その他は第 1 表に示す。

第 1 表

\begin{tabular}{|c|c|c|c|c|c|c|c|c|c|c|c|}
\hline & . & & 排水量 & $L_{0 a} \quad \mathrm{~m}$ & $L_{p p} \quad \mathrm{~m}$ & $B \mathrm{~m}$ & $D \mathrm{~m}$ & $d \mathrm{~m}$ & $C_{B}$ & $V_{s} \quad \mathrm{kt}$ & $V \max _{\mathrm{kt}}$ \\
\hline 模 & 型 & 船 & $100.82^{\mathrm{kg}}$ & 2.699 & 2.500 & 0.342 & 0.204 & 0.161 & 0.728 & & \\
\hline 笑 & & 船 & 13,870 & 138.19 & 128.19 & 17.50 & 10.40 & 8.25 & 0.728 & 13.25 & 16.42 \\
\hline
\end{tabular}


绱模型のピッチング及びヒービングの週期は夫々

$$
T_{p}=0.985 \mathrm{sec}, \quad \text { 及び } T_{h}=0.945 \mathrm{sec}
$$

に調整した。

b） 実験の方法及びその系列

東京大学工学部の船舶抵抗試験水槽に於て曳航実験を行つた。その方法は從来普通に行われている方法により， サージングに対してはバネで押えて $\pm 5 \mathrm{~cm}$ 程度の動きを許し得る様にした。徉つて実船の運動とは澉密には一 致しない。

実験は波長 $\lambda$ を $2.40 \mathrm{~m}$ にして, 船の速度を $1.33,1.03,0.74,0.52$, 及び $0.29 \mathrm{~m} / \mathrm{sec}$ の 5 段埥に, 波高 を各々の場合に 6,9 及び $12 \mathrm{~cm}$ に变えた系列と, 船の速度を $1.20 \mathrm{~m} / \mathrm{sec}$ とし, 波長を $3.20,2.80,2.40$, 2.05 及び $1.70 \mathrm{~m}$ の 5 段階に, 波高は同じく 6,9 及び $12 \mathrm{~cm}$ の 3 段階に变えた 2 系列の実験を行つた。但し 造波装置のスタビライザーの故障の為計画の沒高, 波長が得られなかつたものがある。

c） 水圧の測定

水圧の測定は先に著者の一人が発表した平面板の水面㣫撃圧測定実験 (1) に用いたものと同型の水压計を用い

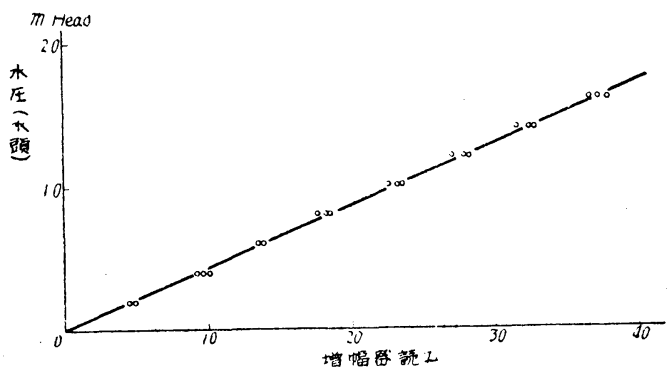

第1图 GAUGE No.24 検定曲線

た。即ち燐青銅の棒より直径 $20 \mathrm{~mm}$, 厚さ $0.3 \mathrm{~mm}$ に削り出した膜板に SR-4 㤠歪形を貼布して加任時の 歪から水圧を测るものである。第 1 図にこの水生計の

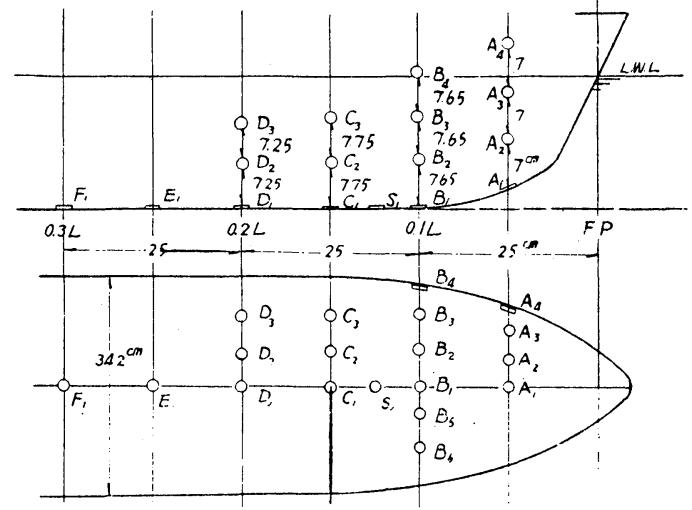

註 各断面に於计る数字は Girth に浴つての距離 (cm) を表わす 第 2 図模型水圧計配置概路

検定曲線の一例を示す。この水珐㖕 19 简を第 2 図に示守位置に模型船 に孔を紫つて外板面と同一面に取付

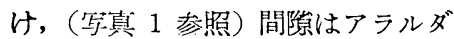
イト樹脂を充填して水密を保たしめ た。雷の测定には導線を電車上に導 き，6素子動的歪测定装瀑を用い， 6 素子電磁オッシログラフで部録し た。同時には 6 点しか测れないので 切換装幒を用い走行中にスゥイッチ 切换により全点を测定した。修間放 充填の不工合から実験の進行と其に 絶縁低下し，放萧の止むなきに至つ。 た水圧計が数簓むつた。

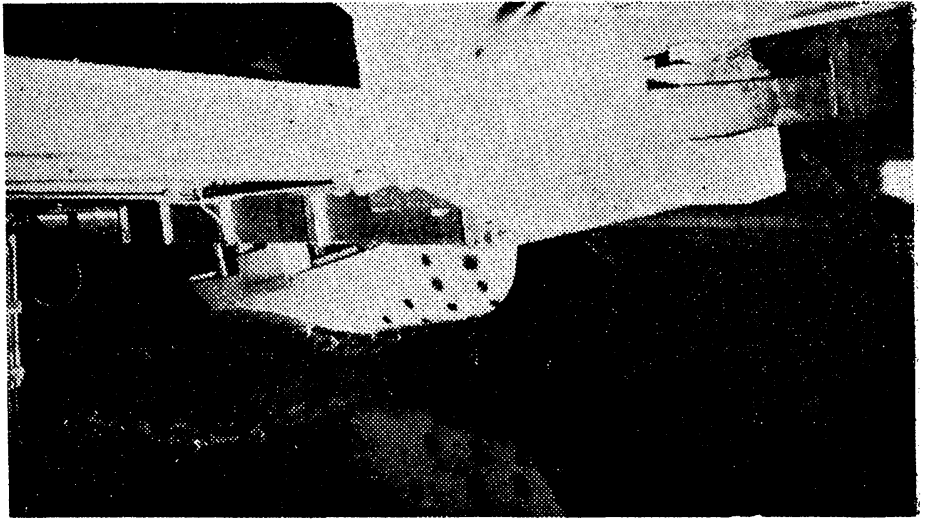

写 真 1

\section{§3. 実験結果及びその考察}

実験結果水圧計で測定した船底部に於ける最大圧力（水頭 $\mathrm{cm}$ にて）を第 2 表に示す。第 2 表には大体船首 船底が水上に現れて水面㣫撃をしたと思われるものを採食したが※印を附したものは果してスラミングをして いるかどうか疑わしいるのである。佮オッシログラムの例を第 3 図に示す。記録された变位は空中に出たもので 
第 2 表 最大圧力 測 定 值

\begin{tabular}{|c|c|c|c|c|c|c|c|c|}
\hline 実跧番号 & $\begin{array}{c}\text { 波高 }\left(2 a_{w}\right) \\
\mathrm{cm}\end{array} \mid$ & $\begin{array}{c}\text { 波長 }(\lambda) \\
\mathrm{cm}\end{array}$ & $\begin{array}{c}\text { heaving }\left(2 a_{h}\right) \\
\mathrm{cm}\end{array}$ & $\left\{\begin{array}{c}\text { pitching }\left(2 \theta_{p}\right) \\
\text { degree }\end{array}\right.$ & $\begin{array}{c}\text { 船速 }(V) \\
\mathrm{m} / \mathrm{sec}\end{array}$ & $\begin{array}{c}\text { 最大压力 } \\
\left(P_{\max }\right) \\
\mathrm{cm} \mathrm{H}\end{array}$ & $\begin{array}{l}P_{\max } \text { 示す } \\
\text { Gauge 位最 }\end{array}$ & 備 \\
\hline 16 & 8.5 & 234 & 1.6 & 3.7 & 1.383 & 27 & $A_{1}$ & \\
\hline 17 & 10.3 & 227 & 3.9 & 7.2 & .276 & 28 & $A_{1}$ & \\
\hline 18 & 11.1 & 214 & 3.7 & 5.0 & .562 & 36 & $A_{1}$ & \\
\hline 19 & 11.3 & 221 & 2.6 & 6.8 & .745 & 48 & $\mathbf{B}_{1}$ & \\
\hline 20 & 11.5 & 226 & 1.9 & 5.3 & 1.098 & 43 & $\mathrm{C}_{1}$ & \\
\hline 21 & 12.2 & 168 & 1.4 & 1.0 & .772 & 30 & $\mathbf{A}_{1}$ & $43\left(A_{2}\right)$ \\
\hline 22 & 11.5 & 190 & 1.2 & 1.6 & .744 & 23 & $A_{1}$ & $32\left(\mathrm{~A}_{3}\right)$ \\
\hline 23 & 11.0 & 236 & 3.7 & 3.8 & .723 & 42 & $\mathrm{~B}_{1}$ & \\
\hline 24 & 12.3 & 290 & 6.9 & 5.6 & .766 & 46 & B5 & \\
\hline 26 & 8.9 & 175 & 9.9 & 0.3 & .760 & 20 & B5 & $34\left(\mathrm{~A}_{3}\right)$ \\
\hline 27 & 9.1 & 220 & 10.1 & 2.3 & .743 & 38 & B5 & $45\left(\mathrm{~A}_{2}\right)$ \\
\hline 28 & 9.4 & 238 & 3.1 & 3.8 & .716 & 50 & $\mathrm{~B}_{1}$ & \\
\hline 29 & 9.4 & 276 & 4.6 & 4.3 & .725 & 40 & $\mathrm{~B}_{2}$ & $76\left(\mathrm{~B}_{6}\right)$ \\
\hline 30 & 11.1 & 335 & 11.2 & 6.0 & .741 & 54 & $\mathbf{B}_{2}$ & \\
\hline 31 & 11.6 & 318 & 9.8 & 5.3 & .985 & 65 & $B_{1}$ & \\
\hline 32 & 12.2 & 290 & 6.1 & 5.9 & .718 & 60 & $\mathrm{~B}_{1}$ & \\
\hline 33 & 13.1 & 302 & 7.9 & 2.7 & .512 & 33 & B5 & \\
\hline 34 & 13.6 & 299 & 4.9 & 4.8 & .285 & 42 & $\mathrm{~B}_{1}$ & \\
\hline 73 & 6.6 & 346 & 5.6 & 3.2 & .743 & 20 & $\mathrm{~B}_{2}$ & $※$ \\
\hline 74 & 5.0 & 283 & 3.8 & 2.7 & .755 & 24 & $\mathrm{~B}_{1}$ & $※$ \\
\hline 75 & 4.2 & 267 & 3.2 & 2.1 & .698 & 20 & $\mathrm{~B}_{2}$ & ※ \\
\hline 76 & 6.6 & 232 & 1.3 & 1.7 & .710 & 20 & $A_{1}$ & $※$ \\
\hline 77 & 6.4 & 186 & 0.8 & 1.0 & .716 & 14 & $A_{1}$ & $※$ \\
\hline 78 & 5.9 & 195 & 1.0 & 0.5 & .693 & 10 & $A_{1}$ & $※$ \\
\hline 79 & 12.2 & 346 & 12.8 & 6.3 & 1.314 & 63 & $\mathrm{~B}_{1}$ & \\
\hline 89 & 9.2 & 269 & 3.6 & 5.6 & .744 & 50 & $\mathrm{~B}_{1}$ & \\
\hline 91 & 6.0 & 195 & 1.0 & 1.0 & .780 & 18 & $\mathrm{~B}_{2}$ & $※$ \\
\hline 92 & 4.5 & 268 & 1. 6 & 3.2 & .783 & 24 & $\mathrm{~S}_{1}$ & $※$ \\
\hline 93 & 6.3 & 292 & 2.2 & 3.7 & .705 & 25 & $S_{1}$ & $※$ \\
\hline 94 & 5.2 & 254 & 1.0 & 3.2 & .765 & 29 & $S_{1}$ & $※$ \\
\hline
\end{tabular}

註 ※四は, 最大圧力を示す Gauge が水面に出たかどらか疑わしいものを示す。又備考中の数字は全体の最 大圧力が船側部に生じたもの改びてつ測定位置を示す。

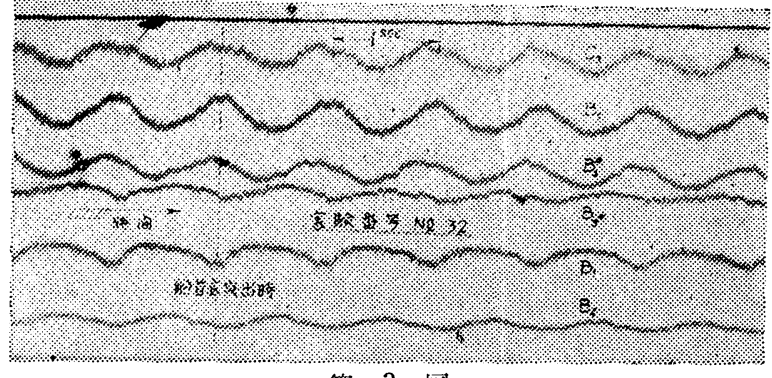

第 3 四

は, 直りに圧力の絶対值を示すが, 運動中全 く沒水状態にあるものは圧力変化の量のみを 示すことになる。空中に出たものは図中に水 平部を有するので判別される。又水任分布の 一例を第 4 図に示す。大体 $\mathrm{B}_{1}$ 点附近即ち $\mathrm{F}$. P. から $0.1 L$ 附近で最大圧力を示すが，船 底と波面との相対運動は複雑であるのて， $\mathrm{B}_{1}$ 点以外の点で最大珐力が示されるものも相当 数ある。船底と波面の相対速度は F.P. で一

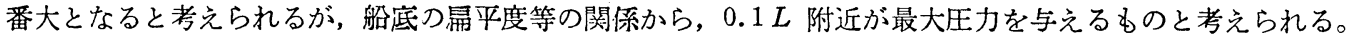
この最大圧力を出会週期をもとにしてプロットしたのが第 5 図である。図で見る様出会週期と固有週期との 比が 1.0〜1.1 附近で大きな圧力を示す。佾当然のことながら波高は大なる程生力は大となつている。 


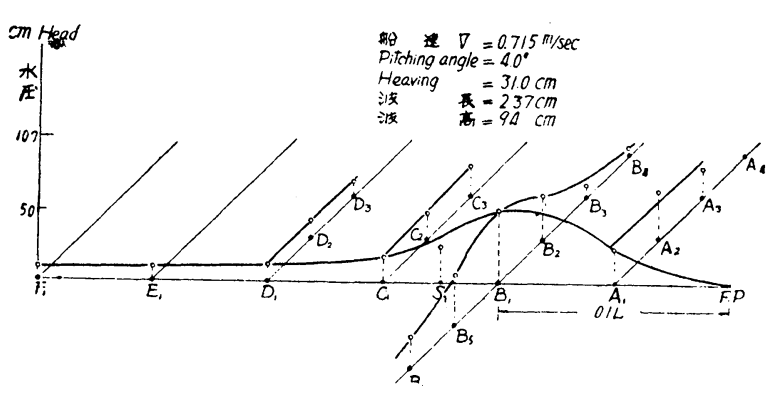

第4因 No.28 水压分布図

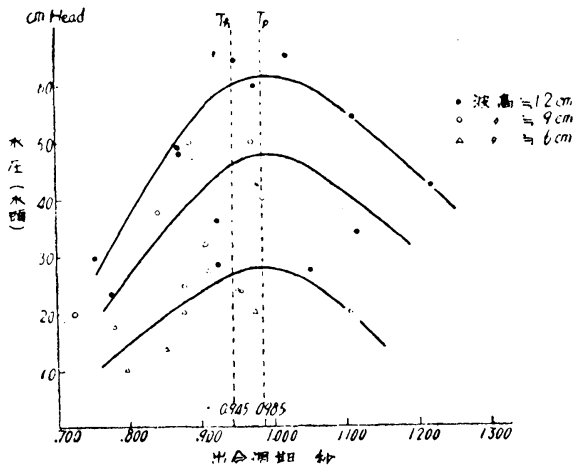

第 5 圀

次に最大圧力を上下摇の振幅の自乗, 綎摇角の自乗及び船と波の相対速度の自乗を現すものとして $A^{2} n^{2}$ を横 軸にとつてプロットしたのが夫々第 6 図, 第 7 図及び第 8 図である。但し

$$
A^{2} n^{2}=\left(a_{n^{2}}+a_{p}^{2}+a_{w}^{2}\right) n^{2}
$$

$a_{h}, a_{p}$ 及び $a_{w}$ は夫々上下摇, 縦摇及び波の振幅であり, $n$ はその円振動数である。(附録参照) 份上式は正確

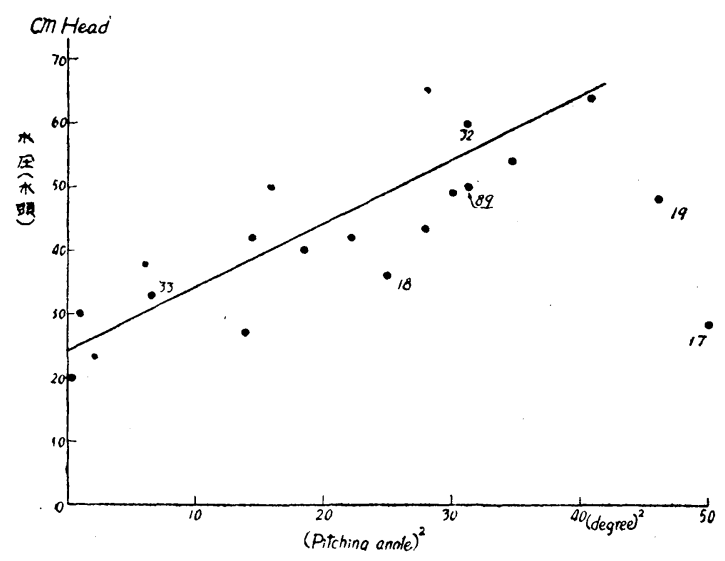

第 6 因

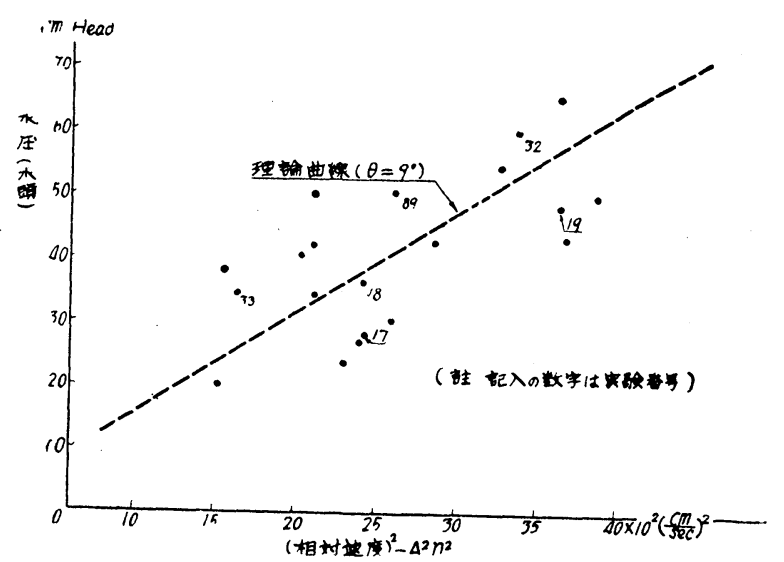

第 8 四

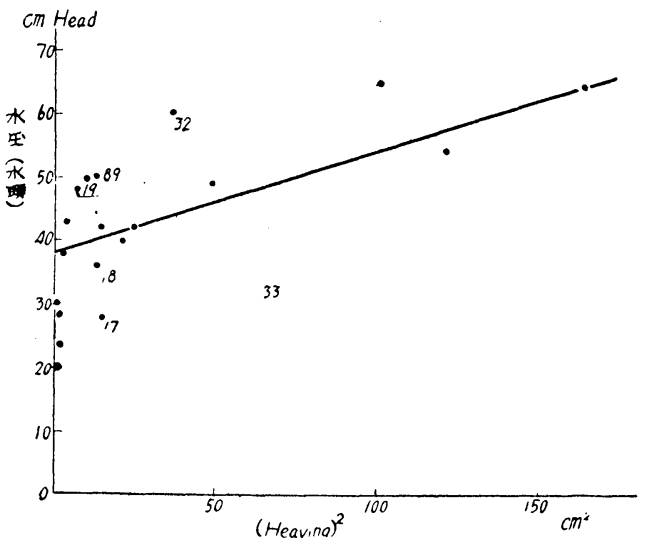

第 7 図

には相対速度の自乘を現さないが，一応の目安 としてとつた。以上の図から判る様に，スラミ ング時の最大圧力は, 本実験に於ては上下摇に より主として支配されるとの説〔2], 縦摇によ り主として支配されると云う説 [3]よりも，第 8 図の相対速度により主として支配されると考 える方が適当の様である。図中に引いた直線は 著者の一人が先に平板の水面落下衙撃実験で得 た結果 [4]の式

$P_{\max }=0.5 \pi \rho(A n)^{2} /(0.63 \tan \theta)$

但し $\theta$ は船底と波面のなす角度, $\rho$ は水の 密度。

を用いて計算した值で， $\theta=9^{\circ}$ と採ると大体実 験值の平均を通るとい5意味である。船の場合 に日をいくらにとれば良いかは難しい問題であるが，この値は左程実情と離れているとは思われない。 本実験で得られた最大圧力は静水圧の約 4 5 倍程度であるが，これは規則沒中の值であり不規則波の場合に 
はもつと大きな值を示すであろうことは想像に難くない。侗規則波の場合も過渡現象的には更に大きい值が現出 する。又船側部に船底部よりも大きな圧力が計測された例があるが，これは波と船との間の不規則な運動のあつ たことを示している。

\section{§4. 結訔}

著者等は日聖丸の木製模型を使つて，波浪中を曳航実験を行い，スラミングの際に船首船底に受ける衝撃圧力 を特に製作した水仿計を用いて測定した。その結果

1）本実験に於ては衝撃圧力は F.P. から大体 $0.1 \mathrm{~L}$ の附近で最大值を示し, 普通に実船で経験される絬果 そ同じ傾向であつた。そして $0.25 L$ より後では殆んぞ圧力は問題にならない。

2）最大の圧力は本実験の如く規則波の場合には静水圧の約 4 5 倍で, 大体船の波面に対する相対速度に関 係して決まると考えて良い。そしてその圧力は平面板の水面落下衝撃の際の值から推定し得る。

3） スラミングの激しく現れるのは波長が船長の約 1.1 1.2 倍附近で起る様である。

最後に本実験は文部省科学研究綜合研究「波浪中に於沙船体の強度並びに運航性能について」の一部として 研究費の補助を得て行われたもので,ここに記して感謝の意を表する。又水槽実験輻䡍の折榵にも不拘水槽使用 の許諾を与えられた山県教授, 並びに実験に彷事された関係諸氏の厚意に感謝の意を表したい。

\section{附録}

\section{§1。船と波の相対遇動}

静水面上に $x, y$ 軸をとり， $x$ 軸が船の進行方向に一致する様に定め, $z$ 軸を垂直上向にとる。波長 $\lambda$ の波が $V_{w}=(g \lambda / 2 \pi)^{1 / 2}$ の速さで $x$ の負の方向に進むものとする。簡単の為に波形を sine 型とすると, 時間 $t$ に於ては $z=a_{w} \cos 2 \pi\left(V_{w} t+x\right) / \lambda$

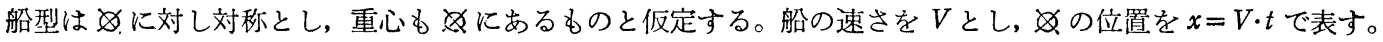

船の運動による波形のくずれ等の二次的のものを無視すると, 㰡に於ける波の高さ $z$ ぬ, 傾斜 $z^{\prime}$ 汹は夫々次の 様になる。

但乙

$$
z_{\Varangle}=a_{w} \cos n \tau, \quad \boldsymbol{z}^{\prime}=a_{w} \cos \left(n t+\frac{\pi}{2}\right)
$$

船は $z$ 及び $z^{\prime}$ に比例する力で上下摇及び，緃摇を強制されるが，減衰力は相当大であるから〔5】強制動摇 の項のみを考方る。上下摇及び䋛摇角は夫々次の様になる。

$$
a_{h} \cos \left(n t-\varepsilon_{h}\right), \quad \theta_{p} \cos \left(n t+\frac{\pi}{2}-\varepsilon_{p}\right)
$$

但し $a_{h}>0, \theta_{p}>0$ 及び $\pi \geqq \varepsilon_{h}\left(\varepsilon_{p}\right) \geqq 0$,

$a_{h}, \theta_{p}$ は $a_{w}$ 並びに夫々の固有週期 $T_{h}, T_{p}$ 及び滅衰力で定まる。

時間 $t=0$ で坐標 $(l, y,-h)$ の外板上の点 $Q$ に於ける波の高さ $z_{Q}$ は次式で与えられる。

$$
z_{Q}=h+a_{w} \cos \left(n t+\varepsilon_{w}\right)-a_{h} \cos \left(n t-\varepsilon_{h}\right)-a_{p} \cos \left(n t+\pi / 2-\varepsilon_{p}\right)
$$

但ᄂ $\varepsilon_{w}=2 \pi l / \lambda, \quad a_{p}=\theta_{p} \cdot l$.

上式を書直すと

$$
\begin{aligned}
& z_{Q}=h+A \cos (n t-\varepsilon) \\
& A=\left[a_{w}{ }^{2}+a_{h}{ }^{2}+a_{p}{ }^{2}-2 a_{w}\left\{a_{h} \cos \left(\varepsilon_{h}+\varepsilon_{w}\right)+a_{p}\left(\varepsilon_{p}+\varepsilon_{w}\right)\right\}-2 a_{h} a_{p} \sin \left(\varepsilon_{h}-\varepsilon_{p}\right)\right]^{1 / 2} \\
& \tan \left(\varepsilon+\varepsilon_{w}\right)=\left\{-a_{h} \sin \left(\varepsilon_{h}+\varepsilon_{w}\right)+a_{p} \cos \left(\varepsilon_{p}+\varepsilon_{w}\right)\right\} /\left\{a_{w}-a_{h} \cos \left(\omega_{h}+\varepsilon_{w}\right)-a_{p} \sin \left(\varepsilon_{p}+\varepsilon_{w}\right)\right\} .
\end{aligned}
$$

上下摇及び縦摇の理論 $[5,6]$ によると， $a_{h} / a_{w}$ は $\lambda / L$ が 1.0 程度以上で, $a_{p} / a_{w}$ は $\lambda / L$ が 0.8 程度以上 で急激に大となることが知られている。(4) 式に於て共振の場合を考完， $\varepsilon_{p} \doteqdot \pi / 2, \varepsilon_{h} \doteqdot \pi / 2$ (船の場合 $T_{h} \doteqdot T_{p}$ のことが多いから共に:共振にあるとする）とすると

$$
\begin{aligned}
& A=\left\{a_{w^{2}}+a_{h}{ }^{2}+a_{p^{2}}+2 a_{w}\left(a_{h}{ }^{2}+a_{p}{ }^{2}\right)^{1 / 2} \sin \left(\varepsilon_{w}-\varepsilon_{1}\right)\right\}^{1 / 2} \\
& \tan \left(\varepsilon+\varepsilon_{w}\right)=-\cos \left(\varepsilon_{w}-\varepsilon_{1}\right) /\left\{a_{w}\left(a_{h}{ }^{2}+a_{p}{ }^{2}\right)^{-1 / 2}+\sin \left(\varepsilon_{w}-\varepsilon_{1}\right)\right\} \\
& \tan \varepsilon_{1}=a_{p} / a_{h}
\end{aligned}
$$

そなり, 振幅 $A$, 位相 $\varepsilon$ は共に $\varepsilon_{w}$ 即ち $l / \lambda$ の変化によつて子変化し, その模様は複雑である。 


\section{§2. 船首船底の受ける圧カについての考案}

水面㣫揧の理論 $[4,7,8]$ によると, 㣫撃圧力は大略

$$
\left[m^{\prime}\left(z_{k}\right) \dot{z}^{2}+m\left(z_{k}\right) \ddot{z}\right] / b\left(z_{k}\right)
$$

の形で与えられる。但し $\boldsymbol{z}_{k}$ は竜骨からの水位で, $m\left(\boldsymbol{z}_{k}\right)$ はそのときの水の附加質量, $b\left(\boldsymbol{z}_{k}\right)$ は吃水面の幅である。

スラミングの様に船底が水面上に出て㣫撃する様な場合には (4)の関係は綮密には成立しないが，(4) が成立 つものとして（6）に代入して考光ると，玏は $A^{2} n^{2}$ に比例する項と $A n^{2}$ の項とより成ることがわかる。扁平 な船底が水面を㣫撃するときは $m^{\prime}(z)$ の值が大きな値となり，第 1 項の $A^{2} n^{2}$ の項が大きくなることが考兄ら れる。又 $V$ 型の船底の場合には $m(z) \propto m_{0}\left[b\left(z_{k}\right)\right]^{2}=m_{1} z_{k^{2}}$ となるので, 同様に禹者とも $A^{2} n^{2}$ に比例するこ とになる。

佾衝撃圧力の大きさ及びその時間的変化の詳細を議論するには，二次的に生ずる波の影響，渦抵抗の影響等を

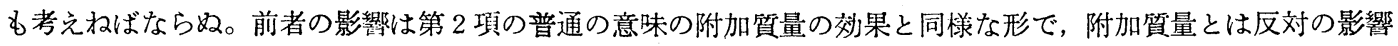
を生ずる。[9]この場合 $n\{b / g\}^{1 / 2}$ が小さいから船幅程度の波となり，この影響は可成りのものと思われる。渦 抵抗については $\dot{z}<0$ の場合, 即ち船が波から相対的に浮上る場合にのみ存在し, (6) の第 1 項と同じ形とな り符号は逆となる。この影響によつて压力の波形が沒入時と浮揚時とで非対称となることが説明される。

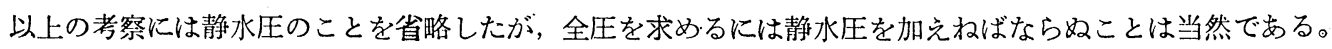

\section{交献}

〔1]藤 田 变; 平面板の水面衝揧について, 造船協会論文集, 第 94 号 p. 105

[2] J. L. Kent; The Cause and Prevention of Slamming of Ship in a Seaway. Trans. N-E. C Inst. Vol. 65 (1948-9) p. 451

〔3〕渡辺恵弘; 船首底衝撃について, 造船協会論文集, 第 93 号 p. 65

[4]藤田 譲; 水面衝撃理論, 東大二工卒業論文 (昭 21)

[5] Ch. Igonet; Pitching Experiments on Models Moored at One Point, Shipbr. April (1940) p. 138

[6]造船協会編；船舶工学便临，第 2 巻（昭 25) p. 136-140

[7] H.Wagner; Über die Landung von Seeflugzeugen. Z.F.M. Bd. 22 (1931) s.1

[8]渡辺恵弘; 波浪に上る船首底衝慗の一般理論, 九大流研報告 第 3 巻（昭 21） p. 1

〔9〕山本善之; 周期運動をする没水体について, 造船協会昭 21 年秋期講演会にて発表 